\title{
Estuarine demersal fish assemblage from a transition region between the tropics and the subtropics of the South Atlantic
}

\author{
Mauricio Hostim-Silva ${ }^{1}$ \\ Arthur da Costa Lima ${ }^{2}$ \\ Henry Louis Spach $^{3}$ \\ Ana Carolina dos Passos ${ }^{4 *}$ \\ Junio Damasceno de Souza ${ }^{4}$

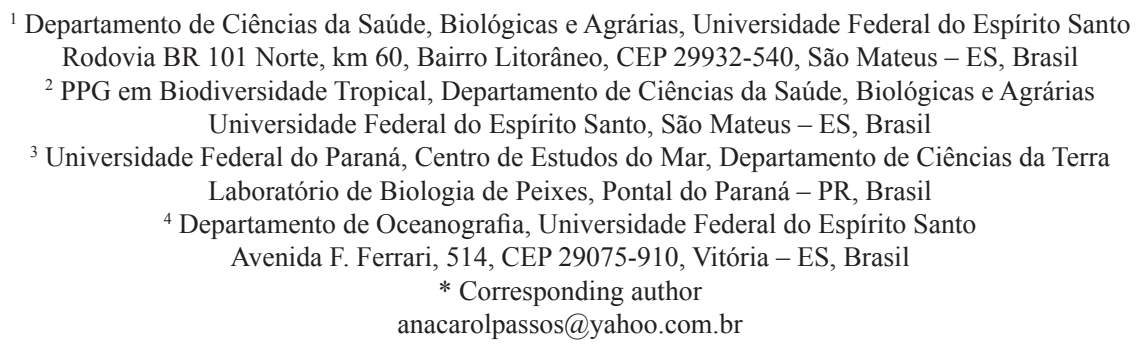

Submetido em 24/11/2012

Aceito para publicação em 26/06/2013

\section{Resumo}

Peixes de uma região de transição entre a área tropical e subtropical do Atlântico Sul. O estado do Espírito Santo está inserido na Região Central do Brasil, onde a produtividade biológica é considerada baixa, típica das regiões tropicais. O objetivo deste trabalho é apresentar uma lista de espécies demersais atualizada no ambiente estuarino a partir do conhecimento atual dos peixes no norte do Espírito Santo. Este trabalho é baseado na compilação de dados coletados mensalmente por rede de arrasto. A ictiofauna é composta por 57 espécies, distribuídas em 10 ordens e 32 famílias. Sciaenidae foi a família com maior número de espécies (8), seguida por Carangidae e Gerreidae, cada uma com quatro espécies. Esse resultado coincide com o encontrado para a costa do Brasil e para a costa do Atlântico Sul. Em termos de números de espécies, é importante notar que a riqueza total de espécies nos estuários ao norte do Espírito Santo é menor do que aquela reportada em outros estuários da costa do Atlântico Sul Oeste. A maioria das espécies está amplamente distribuída ao longo do Atlântico Oeste. Apenas uma pequena parte (14\%) da fauna do norte do ES foi avaliada quanto ao risco de extinção. Apesar disso, a área deve ser prioritária para conservação devido às espécies sobreexplotadas e em perigo de extinção.

Palavras-chave: Atlântico Sul Oeste; Espírito Santo; Ictiofauna; Lista de espécies

\section{Abstract}

The coastal state of Espírito Santo is in the central region of Brazil, where biological productivity is considered low. The objective of this work is to present a current list of demersal, estuarine fish from northern Espírito Santo. This work is based on the compilation of data collected monthly using trawl nets. The ichthyofauna 
comprises 57 species, within 10 orders and 32 families. The family Sciaenidae has the largest number of species (8), followed by Carangidae (4) and Gerreidae (4). This coincides with what has been found for the Brazilian coast and for the coast of the South Atlantic. It is important to note that the total species richness in the estuaries of northern Espírito Santo is lower than other estuaries of the South West Atlantic coast. Most of the species are widely distributed in the Western Atlantic. Only a small part (14\%) of the fauna of northern Espírito Santo was evaluated in regards to risk of extinction, but conservation should be prioritized in the area due to overexploitation of species.

Key words: Espírito Santo State; Ichthyofauna; South West Atlantic; Species list

\section{Introduction}

Compilations of ichthyofauna from the South West Atlantic are important for two reasons: to improve our understanding of the geographical distribution and macro-ecological traits of estuarine fish from this region (BARLETTA; BLABER 2007) and to support conservation efforts (BARLETTA et al., 2010). Fish diversity is high in estuarine environments, and is threatened by anthropic activities, such as overfishing, the introduction of exotic species, activities related to ports and petroleum, and loss of habitat.

The state of Espírito Santo (18 $22^{\prime} \mathrm{S} ; 2^{\circ} 19^{\circ} \mathrm{S}$ ), on the southeastern coast of Brazil, is in the tropicalsubtropical transition zone. It is located in the central region of the country (Espírito Santo and southern Bahia), and has low biological productivity (typical of tropical regions). Although it possesses important estuaries, the number of studies in the literature about this region is low and needs to be increased (ANDRADETUBINO et al., 2008).

There are some recent studies about estuarine fish from Espírito Santo. Chagas et al. (2006) studied Vitória Bay and pointed out the importance of this transition region for ichthyofauna. Sarmento-Soares et al. (2012) and Sarmento-Soares and Martins-Pinheiro (2012) sampled fish populations in the northern and southern basins of the state, including estuarine environments. Other studies in Espírito Santo have focused on ichthyoplankton (COSER et al., 2007), demersal fish (PINHEIRO et al., 2011), and fish assemblages in tide pools (MACIEIRA; JOYEUX, 2011) and along sandy beaches (ANDRADE et al., 2012).

The objective of this work is to present a current species list of the demersal fishes of northern Espírito
Santo (estuaries of Conceição da Barra and Barra Nova). Comments about geographic distribution of the species and their conservation status are provided.

\section{Materials and Methods}

\section{Study area}

The Cricaré River basin, located in northern Espírito Santo, covers approximately $13,500 \mathrm{~km}^{2}$. It is formed by the Cotaxé and Cricaré rivers, which both have their headwaters situated in the state of Minas Gerais. The confluence of these rivers occurs in São Mateus and is referred to as the Cricaré River or the São Mateus River. The São Mateus River flows north and drains into the Atlantic Ocean in Conceição da Barra (Espírito Santo). As a tributary of the Cricaré River, the Mariricu River flows south and drains into Barra Nova (Espírito Santo), forming the estuary of Barra Nova (Figure 1).

The estuary of São Mateus River in Conceição da Barra (3943'56.3"W; $18^{\circ} 35^{\prime} 59.8^{\prime}$ 'S) is mainly characterized by mangrove vegetation, composed of Rhizophora mangle (red mangrove) and Laguncularia racemosa (white mangrove), and occupies $11 \mathrm{~km}^{2}$ (SILVA et al., 2005). In the estuary of Barra Nova (39 44'47.5'W; $18^{\circ} 57^{\prime}$ '05.3'S), from the confluence of the Cricaré River and Mariricu River until the mouth, there is a predominance of forests of Avicennia schaueriana (black mangrove) and A. germinans (black mangrove) in the upper course of the river, mixed forests of $R$. mangle, L. racemosa and A. schaueriana in the middle course, and $R$. mangle in the lower course (PETROBRÁS, 2007). The mouth of the Barra Nova River dries up at certain times of the year. 
FIGURE 1: Location of the estuaries of the São Mateus River (Barra Nova). Sampling sites in the estuary of Conceição da Barra: Site 1 Mouth of the Santana River; Site 2 - Main channel of the São Mateus River; Site 3 - Cove among mangrove; Site 4 - Creek. Collection sites in the estuary of Barra Nova: Site 1 - Dock for boarding and landing; Site 2 - Mouth of the Mariricu River; Site 3 - Near a station for the storage and transport of petroleum; Site 4 - Mariricu River. Satellite images made available by the Sistema Integrado de Bases Geoespaciais do Estado do Espírito Santo (http://www.geobases.es.gov.br/portal/index.php/ navegadores.html). Map author: Felippe Daros.

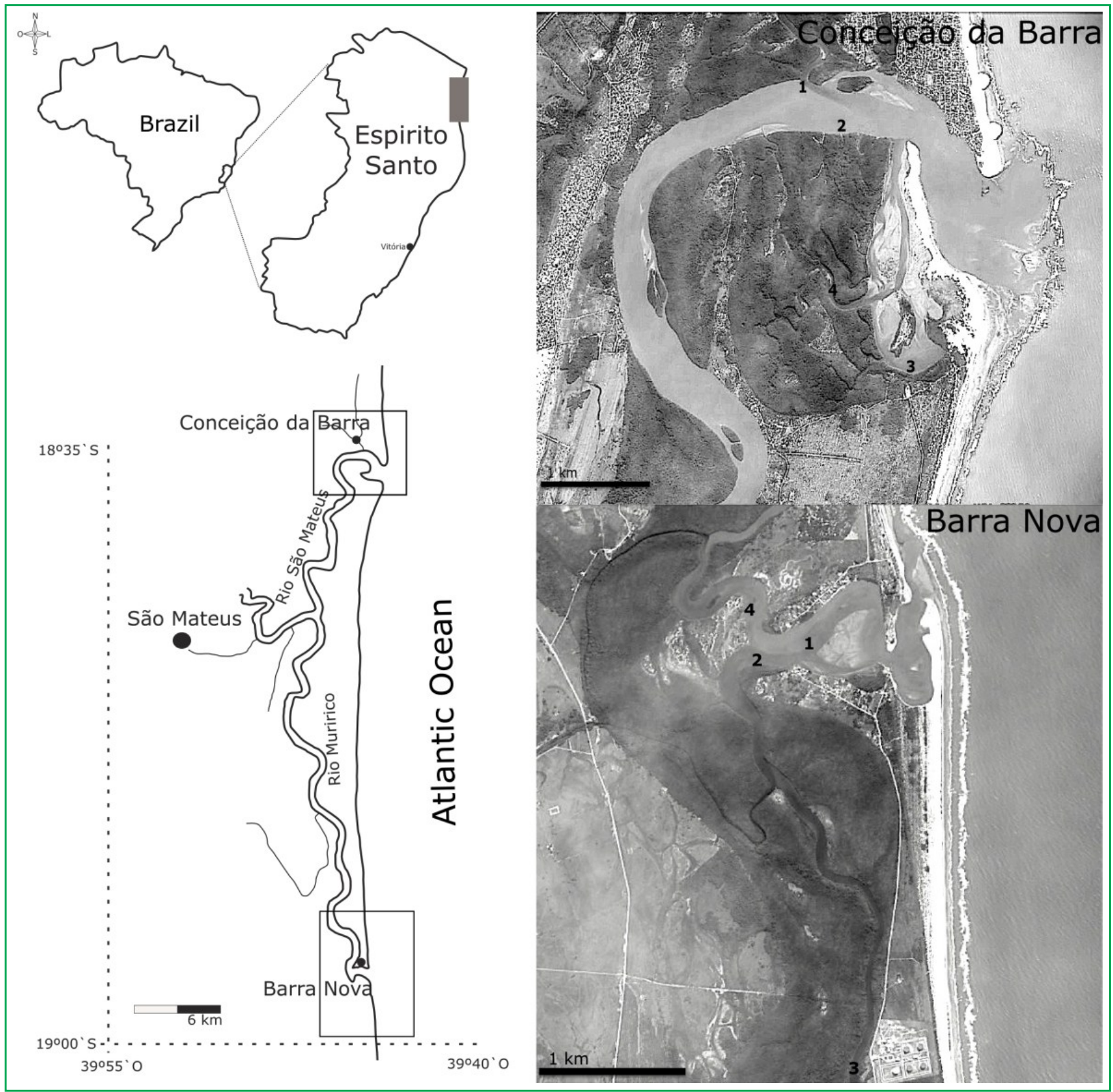


The estuaries of the São Mateus River present semidiurnal tides. The tidal mean was $0.78 \mathrm{~m}$ (mean interval between -0.04 and $1.51 \mathrm{~m}$ during the study period, MINISTÉRIO DA MARINHA, 2011). The climate is tropical and wet, typical of intertropical regions, and has a rainy period in the summer and dry period between April and September.

During the study period, the mean temperature was $23.3^{\circ} \mathrm{C}$, with a maximum temperature of $34.5^{\circ} \mathrm{C}$ in February 2011 and a minimum temperature of $12.0^{\circ} \mathrm{C}$ in August 2011. The region presents two well-defined seasons: a hot season between November and April and a cooler season between May and October. Monthly rainfall varied from $15.4 \mathrm{~mm}$ (September 2011) to $239.8 \mathrm{~mm}$ (April 2011), with well-defined seasons (INMET, 2011).

\section{Data collection}

Sampling started in September 2010 and ended in October 2011. Fish were sampled using trawl nets (2.80 $\mathrm{m}$ wide at mouth by $3.90 \mathrm{~m}$ long; mesh - body: $3.9 \mathrm{~cm}$; bag: $2.2 \mathrm{~cm}$ ). Three five-minute trawls (mean velocity: $2.9 \mathrm{~km} / \mathrm{h}$ ) per site were carried out each month (always at high tide) at 4 sampling sites per estuary (Figure 1). This study was covered by SISBIO license no. 14258 .

All collected fish were separated into plastic bags (by site and trawl number), refrigerated, and sent to the zoology laboratory for identification and biometry. The ichthyofauna was identified to the lowest taxonomic level possible, according to Figueiredo and Menezes (1978; 1980; 2000), Menezes and Figueiredo (1980; 1985), Barletta and Corrêa (1992), and by consulting with specialists. The species listed in this study follow the taxonomic classification and nomenclature of Marceniuk (2005), Craig and Hastings (2007), Smith and Craig (2007), Eschemeyer (2010), and Menezes et al. (2010).

\section{Data treatment}

The distribution of each species was verified in the literature and then assigned to categories adapted from Floeter et al. (2008) and Luiz Jr. et al. (2008), which were the following: $\mathrm{CT}=$ Circumtropical; $\mathrm{TA}=$ Trans-Atlantic (western and eastern Atlantic Ocean); WA $=$ Western Atlantic (northern and southern Atlantic
Ocean); SWA = Southern West Atlantic (from northern Brazil to Argentina); SSWA = Southern South West Atlantic (species with temperate affinities occurring from Argentina and Uruguay to the south and southeast of Brazil); $\mathrm{Ca}=$ Caribbean (from the state of Florida to Venezuela); $\mathrm{Br}=$ Brazilian Province (area between the Orinoco Delta in Venezuela and Santa Catarina State in Brazil); EA = Eastern Atlantic; EP = Eastern Pacific. The conservation status of the species was based on the International Union for Conservation of Nature list (IUCN, 2012), the red list of the Ministério do Meio Ambiente (MMA, 2004; 2008), and the list for São Paulo State (SEMA/SP, 2010). Voucher specimens of most species collected (during our survey) are deposited in the Laboratório de Zoologia do CEUNES (Espírito Santo, Brazil) fish collection and are listed in Appendix 1.

\section{Results and Discussion}

The ichthyofauna of northern Espírito Santo is composed of 57 species, within 10 orders and 32 families (Table 1). Ninety-eight percent (56 spp.) are Actinopterygii and two percent (1 spp.) are Elasmobranchii. Perciformes (36) dominated in number of species, followed by Pleuronectiformes (5) and Clupeiformes (4). The family Sciaenidae had the highest number of species (8), followed by Carangidae (4) and Gerreidae (4). This result coincides with what has been found for the coast of Brazil (ANDRADE-TUBINO et al., 2008) and the coast of the South Atlantic (VIEIRA; MUSICK, 1994), where the Sciaenidae is known to have the greatest number of species. Sciaenidae was also one of the families with the most species in another estuary (Vitória Bay, located $160 \mathrm{~km}$ south of the estuaries in the northern part of the state) (CHAGAS et al., 2006). The richest genera were Achirus, Caranx, Centropomus, Cynoscion, Diapterus, Lutjanus, Mugil, Polydactylus, Pomadasys, and Stellifer (two species each). Comparison of the species compositions of the estuaries of northern Espírito Santo and Vitória Bay (CHAGAS et al., 2006) revealed a relatively high number of species common to both sites (approximately 58\%) and a reasonable number of exclusive species (approximately 42\%). This was expected because the distribution of most of the species that occur in the estuaries overlap. 
TABLE 1: Taxonomic classification of the ichthyofauna found in northern Espírito Santo, Southern West Atlantic. The orders and the families are listed in phylogenetic order according to Eschmeyer (2010) and the species are organized in alphabetic order under each family. Geographical Distribution: CT $=$ circumtropical; TA $=$ TransAtlantic; WA = Western Atlantic; SWA = Southern West Atlantic; SSWA = Southern South West Atlantic; $\mathrm{Ca}=$ Caribbean; $\mathrm{Br}=$ Brazilian Province; EA = Eastern Atlantic; EP = Eastern Pacific; ? = not found. Conservation status according to the IUCN (2012): * = critically endangered. Conservation status according to the MMA (2004; 2008): $\dagger \dagger=$ overexploited. Conservation status according to the SEMA/SP (2010): $\dagger=$ overexploited; $\dagger$ $=$ threatened with overexploitation.

\section{Orders/Families/Species}

Rajiformes

Dasyatidae

Dasyatis guttata (Bloch \& Schneider 1801)

Anguilliformes

Muraenidae

Gymnothorax funebris Ranzani 1839

Ophichthidae

Ophichthus cylindroideus (Ranzani 1839)

Clupeiformes

Engraulidae

Anchovia clupeoides (Swainson 1839)

Anchoviella brevirostris (Günther 1868)

Cetengraulis edentulus (Cuvier 1829)

Pristigasteridae

Odontognathus mucronatus Lacepède 1800

Characiformes

Prochilodontidae

Prochilodus sp.

Siluriformes

Ariidae

Cathorops spixii (Agassiz 1829)

Genidens genidens (Cuvier 1829)

Auchenipteridae

Pseudauchenipterus nodosus (Bloch 1794)

Aulopiformes

Synodontidae

Synodus foetens (Linnaeus 1766)

Scorpaeniformes

Triglidae

Prionotus punctatus (Bloch 1793)

Perciformes

Centropomidae

Centropomus parallelus Poey 1860 .

Centropomus undecimalis (Bloch 1792) \$

Serranidae

Epinephelus itajara (Lichtenstein 1822) $* / \uparrow \uparrow / \uparrow$
$\mathrm{Ca}+\mathrm{Br}$

SSWA

$\mathrm{Ca}+\mathrm{SWA}$

WA

WA

Geographical distribution

$\mathrm{Ca}+\mathrm{Br}$

WA

WA

$\mathrm{Ca}+\mathrm{Br}$

$\mathrm{Br}$

$\mathrm{Ca}+\mathrm{Br}$

WA

$\mathrm{Br}$

WA

WA 
Rypticus randalli Courtenay 1967

Carangidae

Caranx crysos (Mitchill 1815)

TA

Caranx latus Agassiz 1831

TA

Chloroscombrus chrysurus (Linnaeus 1766)

TA

Selene vomer (Linnaeus 1758)

WA

Lutjanidae

Lutjanus jocu (Bloch \& Schneider 1801)

WA

Lutjanus synagris (Linnaeus 1758)

WA

Gerreidae

Diapterus auratus Ranzani 1842

WA

Diapterus rhombeus (Cuvier 1829)

$\mathrm{Ca}+\mathrm{Br}$

Eucinostomus melanopterus (Bleeker 1863)

TA

Eugerres brasilianus (Cuvier 1830)

WA

Haemulidae

Genyatremus luteus (Bloch 1790)

$\mathrm{Ca}+\mathrm{Br}$

Pomadasys corvinaeformis (Steindachner 1868)

$\mathrm{Ca}+\mathrm{SWA}$

Pomadasys ramosus (Poey 1860)

$\mathrm{Ca}+\mathrm{Br}$

Sparidae

Archosargus probatocephalus (Walbaum 1792)

WA

Sciaenidae

Bairdiella ronchus Cuvier 1830)

$\mathrm{Ca}+\mathrm{Br}$

Cynoscion acoupa Lacepède 1801†

$\mathrm{Ca}+\mathrm{SWA}$

Cynoscion leiarchus (Cuvier 1830) \$

$\mathrm{Ca}+\mathrm{Br}$

Larimus breviceps Cuvier 1830

$\mathrm{Ca}+\mathrm{Br}$

Micropogonias furnieri (Desmarest 1823) $\uparrow \uparrow / \uparrow$

$\mathrm{Ca}+\mathrm{SWA}$

Ophioscion punctatissimus Meek \& Hildebrand 1925

$\mathrm{Ca}+\mathrm{Br}$

Stellifer rastrifer (Jordan 1889)

$\mathrm{Br}+\mathrm{SSWA}$

Stellifer stellifer (Bloch 1790)

$\mathrm{Br}$

Polynemidae

Polydactylus oligodon (Günther 1860)

WA

Polydactylus virginicus (Linnaeus 1758)

WA

Mugilidae

Mugil curema Valenciennes 1836

$\mathrm{TA}+\mathrm{EP}$

Mugil liza Valenciennes $1836 \uparrow \uparrow / \uparrow$

WA

Cichlidae

Oreochromis niloticus (Linnaeus 1758)

EA

Uranoscopidae

Astroscopus y-graecum (Cuvier 1829)

WA

Gobiidae

Gobioides broussonnetii Lacepède 1800

WA

Gobionellus oceanicus (Pallas 1770)

WA

Ephippidae

Chaetodipterus faber (Broussonet 1782)

WA

Trichiuridae

Trichiurus lepturus Linnaeus 1758

CT 


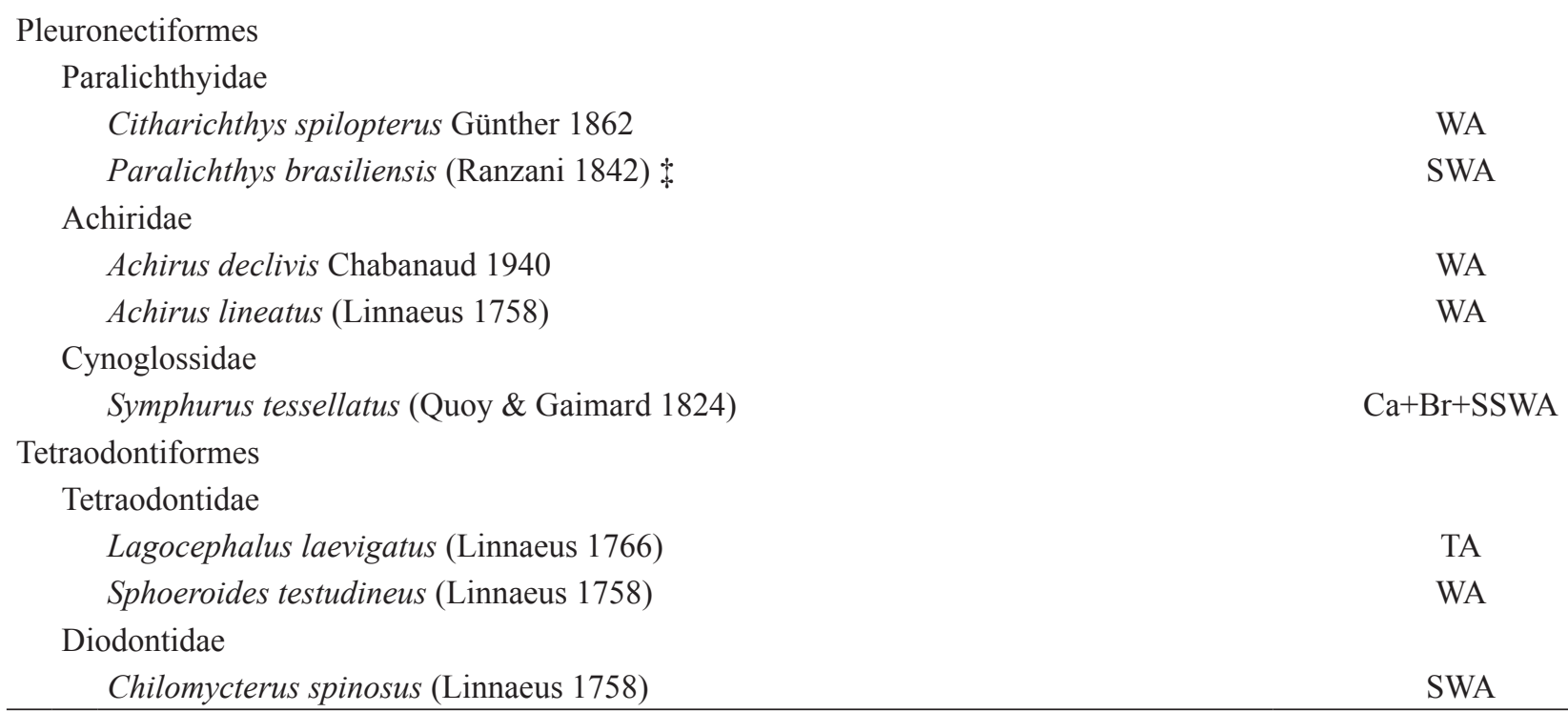

In terms of the number of species, it is important to note that the total species richness in the estuaries in northern Espírito Santo was lower than what has been reported for other estuaries of the Southern West Atlantic coast: Caeté River estuary (82 spp., BARLETTA et al., 2005), Sergipe River estuary (136 spp., ALCÂNTARA, 2006), Curuçá estuary (98 spp., HERCOS, 2006; GIARRIZZO; KRUMME, 2007; SARPEDONTI et al., 2008), Paraguaçu River estuary (124 spp., REIS-FILHO et al., 2010), Baía de Vitória (77 spp., CHAGAS et al., 2006). On the other hand, the size of the sampling areas (Sergipe River estuary $=47.1 \mathrm{~km}^{2}$; Paraguaçu River estuary $=127.9 \mathrm{~km}^{2}$ ) and the effort and strategy of sampling in each of these areas cannot be disregarded in the explanation of these richness differences. In addition, the diversity of estuarine environments, the pluvial patterns, the hydrography, and the oceanographic patterns should be considered.

The species fit well in the categories adapted from the works of Floeter et al. (2008) and Luiz Jr. et al. (2008). Therefore, this adaptation will be used in the future to categorize the geographical distribution of estuarine fishes. Most of the species are widely distributed in the Western Atlantic (approximately 42\%), followed by species restricted to the provinces of the Caribbean and Brazil (species occur in both) (21\%) (Table 1; Figure 2). The fauna of this transition region is widely distributed in the entire Western Atlantic and partially resembles the fauna of the Caribbean and Brazil.
Only a small number $(14 \%-8$ species $)$ of the fauna of northern Espírito Santo was evaluated in regards to risk of extinction: one species is on the IUCN Red List (2012), three are on the red list of the MMA (2004; 2008), and eight are on the red list for São Paulo State (SEMA/SP, 2010) (Table 1). This deficiency is because of the lack of basic information about the biology and ecology of the species. In addition, the regional and national lists should be better publicized so that the data is included in the next IUCN list.

The occurrence of Oreochromis niloticus, an invasive species from the coast of Africa, should also be considered (Eschmeyer, 2010). The species is classified as a pest and has impacted the ecosystem in many ways since its introduction (FROESE; PAULY, 2010). Future studies related to the success of the establishment of this species, and its impact on the local fauna, are recommended.

This study resulted in a list of the demersal, transition estuarine fish of northern Espírito Santo, which was based on diverse spatio-temporal samples. The fauna sampled is widely distributed in the Western Atlantic and resembles the fauna of the Caribbean and Brazil. The diversity of species (57 spp.) is low compared to other systems (keeping in mind the different sizes of the sampling sites, the methods and effort used, and the more specific environmental characteristics). Even so, the study area should be a conservation priority due 
to overexploited and endangered species that occur in this region. Moreover, the local fish fauna is still poorly understood, despite the potential risk of overfishing and activities related to oil, along the coast of Espírito Santo.

\section{Acknowledgments}

Funding was provided by FAPES through a master's degree grant to Arthur da Costa Lima. We would like to thank Felippe Daros for his valuable help with the map.

\section{References}

ALCÂNTARA, A. V. A ictiofauna do estuário do Rio Sergipe. In: ALVES, J. P. H. (Ed.). Rio Sergipe: importância, vulnerabilidade e preservação. São Cristovão: Editora UFS, 2006. p. 111-142.

ANDRADE, R.; BOLZAN, M. S.; CONTAIFER, L. S.; GOMES, M. P.; ALBUQUERQUE, C. Q.; GAELZER, L. R.; MARTINS, A. $\mathrm{S}$. Evidence of sandy beaches as growth grounds for commercial fish in the south-western Atlantic. Pan-American Journal of Aquatic Sciences, Rio Grande, v. 7, n. 2, p. 107-110, 2012.

ANDRADE-TUBINO, M. F.; RIBEIRO, A. L. R.; VIANNA, M. Organização espaço-temporal das ictiocenoses demersais nos ecossistemas estuarinos brasileiros: uma síntese. Oecologia Brasiliensis, Rio de Janeiro, v. 12, n. 4, p. 640-661, 2008.

BARLETTA, M.; BARLETTA-BERGAN, A.; SAINT-PAUL, U.; HUBOLD, G. The role of salinity in structuring the fish assemblages in a tropical estuary. Journal of Fish Biology, Perthshire, v. 66, p. 45-72, 2005.

BARLETTA, M.; BLABER, S. J. M. Comparison of fish assemblages and guilds in tropical habitats of the Embley (IndoWest Pacific) and Caeté (Western Atlantic) estuaries. Bulletin of Marine Science, Miami, v. 80, n. 3, p. 647-680, 2007.

BARLETTA, M.; CORRÊA, M. F. M. Guia para identificação de peixes da costa do Brasil. Curitiba: Editora UFPR, 1992. 121 p.

BARLETTA, M.; JAUREGUIZAR, A. J.; BAIGUN, C.; FONTOURA, N. F.; AGOSTINHO, A. A.; ALMEIDA-VAL, V. M. F.; VAL, A. L.; TORRES, R. A.; JIMENES-SEGURA, L. F.; GIARRIZZO, T.; FABRÉ, N. N.; BATISTA, V. S.; LASSO, C.; TAPHORN, D. C.; COSTA, M. F.; CHAVES, P. T.; VIEIRA, J. P.; CORRÊA, M. F. M. Fish and aquatic habitat conservation in South America: a continental overview with emphasis on neotropical systems. Journal of Fish Biology, Perthshire, v. 76, p. 2118-2176, 2010 .

CHAGAS, L. P.; JOYEUX, J. C.; FONSECA, F. R. Small-scale spatial changes in estuarine fish: subtidal assemblages in tropical Brazil. Journal of the Marine Biological Association of the United Kingdom, Cambridge, v. 86, p. 861-875, 2006.

COSER, L. M.; PEREIRA, B. B.; JOYEUX, J. C. Descrição da comunidade ictioplanctônica e sua distribuição espacial no estuário dos rios Piraquê-Açu e Piraquê-Mirim, Aracruz, ES, Brasil. Interciência, Caracas, v. 32, n. 4, p. 233-241, 2007.
CRAIG, M. T.; HASTINGS, P. A. A molecular phylogeny of the groupers of the subfamily Epinephelinae (Serranidae) with a revised classification of Epinephelini. Ichthyological Research, Tokyo, v. 54, p. 1-17, 2007.

ESCHMEYER, W. N. Catalog of fishes. San Francisco: California Academy of Sciences. Disponível em: $<$ http://www.calacademy. org/research/ichthyology/catalog/>. Acesso em: 20 out. 2010.

FIGUEIREDO, J. L.; MENEZES, N. A. Manual de peixes marinhos do sudeste do Brasil. II. Teleostei (1). São Paulo: Ed. Museu de Zoologia da USP, 1978. 110 p.

FIGUEIREDO, J. L.; MENEZES, N. A. Manual de peixes marinhos do sudeste do Brasil. III. Teleostei (2). São Paulo: Ed. Museu de Zoologia da USP, 1980. 90 p.

FIGUEIREDO, J. L.; MENEZES, N. A. Manual de peixes marinhos do sudeste do Brasil. VI. Teleostei (5). São Paulo: Ed. Museu de Zoologia da USP, 2000. 116 p.

FLOETER, S. R.; ROCHA, L. A.; ROBERTSON, D. R.; JOYEUX, J. C.; SMITH-VANIZ, W. F.; WIRTZ, P.; EDWARDS, A. J.; BARREIROS, J. P.; FERREIRA, C. E. L.; GASPARINI, J. L.; BRITO, A.; FALCÓN, J. M.; BOWEN, B. W.; BERNARDI, G. Atlantic reef fish biogeography and evolution. Journal of Biogeography, New York, v. 35, p. 22-47, 2008.

FROESE, R.; PAULY, D. FishBase. World Wide Web electronic publication. Version (07/2010). Disponível em: <http://www. fishbase.org/home.htm>. Acesso em: 27 out. 2010.

GIARRIZZO, T.; KRUMME, U. Spatial differences and seasonal cyclicity in the intertidal fish fauna from four mangrove creeks in a salinity zone of the Curuçá estuary, north Brazil. Bulletin of Marine Science, Miami, v. 80, n. 3, p. 739-754, 2007.

HERCOS, A. P. Diversidade e variabilidade espaço-temporal da ictiofauna da região estuarina do rio Curuçá município de Curuçá, Pará Brasil. 2006. 123 f. Dissertação (Mestrado em Zoologia) - Universidade Federal do Pará, Belém. 2006.

INMET - Instituto Nacional de Meteorologia. INMET. 2011. Disponível em: <http://www.inmet.gov.br/>. Acesso em: 1 fev. 2012. IUCN - INTERNATIONAL UNION FOR CONSERVATION OF NATURE. IUCN red list of threatened species 2012. Disponível em: <http://www.iucnredlist.org/>. Acesso em: 16 ago. 2012.

LUIZ JR., O. J.; CARVALHO-FILHO, A.; FERREIRA, C. E. L.; FLOETER, S. R.; GASPARINI, J. L.; SAZIMA, I. The reef fish assemblage of the Laje de Santos Marine State Park, Southwestern Atlantic: annotated checklist with comments on abundance, distribution, trophic structure, symbiotic associations, and conservation. Zootaxa, Auckland, v. 1807, p. 1-25, 2008.

MACIEIRA, R. M.; JOYEUX, J. C. Distribution patterns of tidepool fishes on a tropical flat reef. Fishery Bulletin, Seattle, v. 10, n. 3, p. 305-315, 2011.

MARCENIUK, A. P. Chave para identificação das espécies de bagres marinhos (Siluriformes, Ariidae) da costa brasileira. Boletim do Instituto de Pesca, São Paulo, v. 31, n. 2, p. 89-101, 2005.

MENEZES, N. A.; FIGUEIREDO, J. L. Manual de peixes marinhos do sudeste do Brasil. IV. Teleostei (3). São Paulo: Ed. Museu de Zoologia da USP, 1980. 96 p.

MENEZES, N. A.; FIGUEIREDO, J. L. Manual de peixes marinhos do sudeste do Brasil. V. Teleostei (4). São Paulo, Ed. Museu de Zoologia da USP, 1985. 105 p. 
MENEZES, N. A.; OLIVEIRA, C.; NIRCHIO, M. An old taxonomic dilemma: the identity of the western south Atlantic lebranche mullet (Teleostei: Perciformes: Mugilidae). Zootaxa, Auckland, v. 2519, p. 59-68, 2010.

MINISTÉRIO DA MARINHA. Tábua de marés. 2011. Disponível em <http://www.mar.mil.br/dhn/chm/tabuas/index.htm>. Acesso em: 1 fev. 2012.

MMA - Ministério do Meio Ambiente. Instrução Normativa $\mathbf{N}^{0}$ 005, de 21 de maio de 2004. 2004. Disponível em: < http://www. mma.gov.br/estruturas/179/_arquivos/179_05122008033927.pdf >. Acesso em: 19 jan. 2011.

MMA - MINISTÉRIO DO MEIO AMBIENTE. Livro vermelho da fauna brasileira ameaçada de extinção. Vol. 2. Brasília: Ministério do Meio Ambiente, 2008. 1420 p.

PETROBRAS. Diagnóstico ambiental: atividade de produção e escoamento de gás natural e petróleo do Campo de Camarupim, Bacia do Espírito Santo. Vitória: Petrobrás, 2007. p. 283-284.

PINHEIRO, H. T.; MARTINS, A. S.; ARAUJO, J. N. Demersal fish communities may indicate priority áreas for marine resources conservation. Pan-American Journal of Aquatic Sciences, Rio Grande, v. 6, n. 3, p. 210-221, 2011.

REIS-FILHO, J. A.; NUNES, J. A. C. C.; FERREIRA, A. Estuarine ichthyofauna of the Paraguaçu River, Todos os Santos Bay, Bahia, Brazil. Biota Neotropica, Campinas, v. 10, n. 4, p. 301-311, 2010.

SARMENTO-SOARES, L. M.; MARTINS-PINHEIRO, R. F. A fauna de peixes nas bacias do norte do Espírito Santo, Brasil. Sitientibus, série Ciências Biológicas, Feira de Santana, v. 12, n. 1, p. 27-52. 2012.

SARMENTO-SOARES, L. M.; MARTINS-PINHEIRO, R. F.; MARTINELLI, M. M. A fauna de peixes nas bacias do sudeste do Espírito Santo, Brasil. Sitientibus, série Ciências Biológicas, Feira de Santana, v. 12, n. 1, p. 1-25. 2012.

SARPEDONTI, V.; ANUNCIAÇÃO, E. M. S.; NAHUM, V. J. I. Ichthyoplankton variation in two mangrove creeks of the Curuçá estuary, Pará, Brazil. Ecotrópicos, Mérida, v. 21, n. 1, p. 1-12, 2008.

SEMA/SP - SECRETARIA DO MEIO AMBIENTE. Decreto $\mathbf{N}^{\mathbf{o}}$ 56.031, de 20 de julho de 2010. 2010. Disponível em: <http:// www.cetesb.sp.gov.br/licenciamentoo/legislacao/estadual/ decretos/2010_Dec_Est_56031.pdf>. Acesso em: 16 fev. 2011.

SILVA, M. A. B. da; BERNINI, E.; CARMO, T. M. S. do. Características estruturais de bosques de mangue do estuário do rio São Mateus, ES, Brasil. Acta Botanica Brasilica, Feira de Santana, v. 19, p. 465-471, 2005.

SMITH, W. L.; CRAIG, M. T. Casting the Percomorph net widely: the importance of broad taxonomic sampling in the search for the placement of the serranid and percid fishes. Copeia, Lawrence, v. 2007, n. 1, p. 35-55, 2007.

VIEIRA, J. P.; MUSICK, J. A. Fish faunal composition in warmtemperate and tropical estuaries of western Atlantic. Atlântica, Rio Grande, v. 16, p. 31-53, 1994.

\section{Appendix 1}

List of voucher specimens from the estuaries of São Mateus River deposited in the fish collection of the Laboratório de Zoologia do CEUNES (CZNC), organized in alphabetical order by species.

Achirus lineatus-CZNC235; Anchovia clupeoides - CZNC228; Astrocopus y-graecum - CZNC251; Centropomus parallelus - CZNC239; Centropomus undecimalis - CZNC240; Chaetodipterus faber CZNC252; Chloroscombrus chrysurus - CZNC241; Chilomycterus spinosus - CZNC244; Dasyatis guttata - CZNC236; Diapterus auratus - CZNC230; Diapterus rhombeus - CZNC248; Eucinostomus melanopterus - CZNC231; Eugerres brasilianus - CZNC232; Genidens genidens - CZNC229; Gobionellus oceanicus - CZNC234; Gymonothorax funebris - CZNC237; Lagocephalus laevigatus - CZNC242; Larimus breviceps - CZNC249; Lutjanus jocu - CZNC246; Lutjanus synagris - CZNC247; Micropogonias furnieri - CZNC250; Mugil curema - CZNC233; Polidactylus oligodon - CZNC253; Selene vomer - CZNC245; Sphoeroides testudineus - CZNC243; Synodus foetens $-\mathrm{CZNC} 238$ 